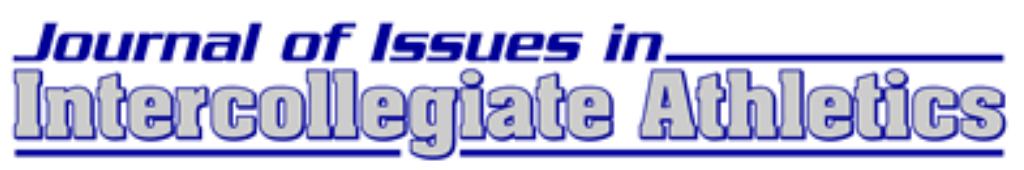

\title{
Bowled Over: Big-Time College Football from the Sixties to the BCS Era
} By Michael Oriard. Published in 2009 by The University of North Carolina Press, Chapel Hill, NC. (352 pages).

Reviewed by

\section{Dr. William Broussard}

Executive Director: Northwestern State University Athletic Association

Recently, as I sat through a theatrically contentious faculty senate meeting in which university appropriations to intercollegiate athletics were hotly debated between faculty, administrators, and athletic administrators, I reflected over the following statement like a mantra:

"From the moment that university administrators [...] realized that the new public passion for intercollegiate football provided opportunities for university building, (universities) have been torn between the competing demands of marketing and educating" (1-2).

This is the backdrop for not only the fierce negotiations between university administrators about the mission of higher education, but also the subtext for conversations never held between ardent college football fans who never step foot on a campus and the most strident defenders of higher education's mission, who never step foot in a college stadium on a Saturday night. As a college football player turned athletic administrator and faculty member, I can appreciate the perspectives of all the negotiating parties. I can also appreciate the importance of perspective to the conveyance of a compelling story.

In the introduction to Bowled Over, author Michael Oriard reveals his analytical approach as ethnographer and historian to introduce his unique perspective on a rich area of consideration that is gaining increasing attention among the higher education studies - the proliferation of college athletics. This approach ultimately proves beneficial, in addition to being quite unique in sport culture criticism. As Mary Louise Pratt points out in "Arts of the Contact Zone," it is important to depict "social spaces where cultures meet, clash, and grapple with each other," especially when one is personally involved in those struggles (a reflective method known as 
autoethnography) (519). All too often, scholarship in sport management and higher education history is author-evacuated, de-contextualized, and personal experience relegated to introductory anecdotes rather than emerging as central to the analysis. The alternative is no better, with vignette vendettas and exculpatory exorcisms by authors who have been personally wronged in one way or another by the machinery and culture of the college sports industry.

In particular, what makes Oriard's perspective so pivotal is that his career as amateur, collegiate and professional football player spanned a decade, which he labels "the long 60's" (5), and contends was the most controversial in organized American football. The years between 1963-1974 not only saw watershed changes in American culture, but those cultural changes had an indelible impact on college sport, and the decade casts a longer and more significant shadow over college football as we know it to this day (6-7). Oriard's first-hand experiences with and living through those changes as student-athlete-turned-professional athlete-turned university professor provide robust context for his often reasonable, and on occasion controversial, foundation-jarring claims.

Among the more controversial claims is that the institution of the one-year scholarship in 1973 transformed amateur athletics irreparably, and, that it was in response to the American cultural trend of 1960's racial upheaval (7). And yet, this claim is made more compelling by Oriard's experiences living through that period and experiencing those changes first hand.

Oriard also details a long list of radical action spanning the country from Washington State, to Wyoming, to Indiana, and Syracuse and many points in between. The everyday actions of players at those institutions challenged the cultural norms that dominated the football landscape previously and attempted to wrest college football from the Conservative and religionist movements Oriard claims had co-opted it in the early half of the twentieth century (46-47). Far from the "dumb jock" stereotype that dominates much thinking about the big-time college football player, football players became focal civil rights heroes in many cases and actually inspired participation in civil rights causes, from Ben Williams' integration of Ole Miss football, the last bastion of segregation in the arch-segregationist SEC (81-84) to Eddie McAshan's integration of the quarterback position at a major southern school (Georgia Tech in 190). Largely influenced by the African-American civil rights movement, and the social movement strategies it popularized in America $^{1}$, players made significant strides in transforming college athletics culture, but as Oriard points out, the rich history of athletes participating and spawning revolutionary action goes back to the strike breakers at Cal, Chicago, and Minnesota at the turn of the $20^{\text {th }}$ century (24). Perspective is important here, because many of these stories have either gone untold, or have been retold to cleanse them of the bigotry and racism that permeated college football and its earliest heroes, the coaches. Oriard's retelling of Bear Bryant's integration of Alabama football is particularly crushing to his The Last Coach mythos

\footnotetext{
${ }^{1}$ I've written about this elsewhere, namely, in "One Foot In: Student-Athlete Advocacy in the Margins of American College Athletics," as part of the University of Washington Intercollegiate Athletic Leadership working paper series. Downloaded from http://csri-jiia.org (O2011 College Sport Research Institute. All rights reserved. Not for commercial use or unauthorized distribution.
} 
as hard-nosed pragmatist committed to winning at all costs, even desegregation (60-62). Instead, we are provided with an analysis of Bryant's decision to integrate his team as one borne both of humiliation and personal loss, not revelation or even the more crass realization that he could not win without black players ${ }^{2}$.

Even at Notre Dame, far from the recently desegregated south, and the more racially progressive West, Oriard witnessed first-hand as student protests of the invasion of Cambodia and Vietnam on his campus were first rejected and eventually given a guarded "go-ahead" by Coach Ara Parseghian, who did not admit publicly that he was anti-war. And though Oriard is careful not to compare superficial cultural changes at Notre Dame (such as the way players were allowed to wear their hair and facial hair during this period changing drastically) to the student protests across the country for substantive social change, participating in and observing those movements at Notre Dame put the larger movement in perspective for him, and showed him once and for all that sport is not above or beyond the politics and culture of American society, but intertwined within it and in some cases, incredibly influential upon it. After all, as Oriard points out, there were black players integrating the SEC before 1970, but to white, southern football purists, Sam Cunningham and USC had as much of an impact on civil rights in the South as did Rosa Parks.

No matter how much credit organized sport is given for providing diverse groups of people the opportunity to consider racial and cultural difference in ways that it may never have been considered otherwise, it's important to note that organized sport does not exist above, beyond, or in a vacuum where such matters do not have an impact. Even the concept of the "student-athlete" as we know it has been shaped by these factors, and Oriard shows us the impact of racial and cultural difference on the shaping of the student-athlete experience through the lenses of history, historiography, and personal experience.

Many take for granted that the idea of the student-athlete is one that is a remnant of ancient times, where young men would train their minds and bodies in conjunction with one another, and the gymnasia served as a space where bodies learned to be elegant and to elocute (see Debra Hawhee's Bodily Arts for an excellent analysis on this topic). Oriard examines the phasing out of the "student-athlete" (and transition to "athlete-student") through analysis of NCAA legislation, examining historical trends, and through personal reflection. Oriard points to a specific historical moment when the NCAA's twice- failed and eventually successful attempt (under the leadership of avowed anti-radical Walter Byers) to pass legislation that eliminated the four-year scholarship provision and reduce it to one-year, renewable contracts between the university and the athlete (46). In doing so, Oriard claims, that the "student-athlete" was eliminated from big time college athletics, and the professionalization that we often cite

\footnotetext{
${ }^{2}$ Oriardi notes that Bryant likely lost a fourth national championship in 1966 because sportswriters did not appreciate his unwillingness to integrate. His undefeated Crimson Tide finished second to 10-0-1 Notre Dame. Downloaded from http://csri-jiia.org

C2011 College Sport Research Institute. All rights reserved. Not for commercial use or unauthorized distribution.
} 
synonymously with college athletics' arms race began in sooth $(130)^{3}$. Again, this footnote provides a perspective on college athletics oft unconsidered, that college athletics has not become the economic behemoth on the accord of local university administrators, or because of historical inevitability or capitalistic compulsion. Rather, because of unintended consequences, sanctioned racism and anti-radicalism, the biggest players in college football now closely resemble its earliest antecedents who hired mercenaries to compete for their institutions, bringing them glory and financial reward.

Oriard does more than suggest that this watershed moment occurred by citing transcripts and news reporting. Rather, he shows how racial upheaval and civil rights movements inspired both revolutionary movement among players and reactionarism among coaches and athletic officials, and he rewrites the institution of the one-year renewable scholarship as a sea change moment. It would become a means by which the NCAA could control player protest against institutional and cultural mores, remove talk of entitlement to workers' rights (130-31), and eventually become the basis by which the NCAA would protect its non-profit status (thus increasing its and its members' profit margins) for decades to come ${ }^{4}$.

Oriard himself observed and participated in the cultural moments which precipitated the one-year scholarship legislation while a student-athlete at Notre Dame. Folks like Oriard, who himself claims to have gone to college for athletic and academic pursuits, are relics of the past, as the renewal is "contingent upon satisfying the coach ... and that players must acquiesce in coaches' increasing demands" (204) and that athletes who desire academic and athletic success are still possible, but succeed "against the system rather than within it" (206). The college football establishment, as well as conservative American political officials, claimed football as a bastion of anti-war and anti-radicalist sentiment, even though on college campuses across the country, these norms were being challenged and coaches who were becoming relics of a time long past became victims of their stubborn refusal to accept their players right to free speech and cultural expression. As he shows through careful narrative that explains how national trends impacted life in South Bend - his "well-barbered" teammates looking like "Eisenhower Republicans" upon his entrance in 1966 - and the painful and humiliating ushering-out of coaches who demanded their players stifle anti-war, anti-religion, and counter-cultural sentiment in all its forms by the time he was cut by the Kansas City Chiefs in 1974 (17-18). In the end, the passage of the one-year renewable scholarship bylaw reasserted the college football establishment's Conservatism by threatening students' rights and set the stage for studentathletes like Oriard to become a true minority in big-time college sport. It also, paved the way for big-time college football's commercialism, and gave credence to critics who claim that their priorities must need place athletics over academics.

\footnotetext{
${ }^{3}$ Even though the practice of recruiting individuals to play for a collegiate team by contract wet back to the late $19^{\text {th }}$ century, Oriardi claims that the one-year renewable contract was the most significant move in the commercialization of college sport ever.

${ }^{4}$ This is the predominant subject matter of Chapter 1, “From the Sidelines of a Football Revolution," pp. 15-56. Downloaded from http://csri-jiia.org (C2011 College Sport Research Institute. All rights reserved. Not for commercial use or unauthorized distribution.
} 
Rhetorically, Oriard's arrival story as student-athlete who lived personally through the times he investigates and analyzes gives him considerable ethos as analyst and his colorful anecdotes as storyteller that make the read enjoyable and insightful. One minor drawback is that the lack of personal experience cited as backdrop for chapters that rely heavily on data to ground his claims leads to a rather dry and sometimes laborious reading. The lack of backgrounding for the drier statistical claims begs for either a co-author with commensurate experience to carry forward the storytelling/analysis juxtaposition, or, consultation with industry professionals coaches, and athletic administrators in particular - who share similar sympathies for studentathletes and universities caught in the arms race of college athletics. Oriard's methodological approach to cementing his central claims via personal narrative, supported by statistical, historical, and anecdotal evidence, suggests how a wider range of disciplinary and interdisciplinary inquiry might prove beneficial to the burgeoning study of American sport culture criticism.

\section{References}

Barra, Allan. (2005). The Last Coach: A Life of Paul “Bear” Bryant. New York: W. W. Norton Press.

Broussard, William. (2009). "One foot in: Student-athlete advocacy in the margins of American college athletics." Issues in Intercollegiate Athletics. 2009-10 working paper series. University of Washington, Seattle.

Hawhee, Debra. (2005). Bodily Arts: Rhetoric and Athletics in Ancient Greece. Austin: University of Texas Press.

Pratt, Mary Louise. (1991). Arts of the contact zone. Profession, 91, 33-40. 